ARAŞTIRMA MAKALESI

\title{
Ebelik ve Hemşirelik Öğrencilerinin Gebelik Öncesi Doğum Korkularını Etkileyen Faktörlerin Belirlenmesi
}

\author{
Burcu AVCIBAY VURGEÇ ${ }^{1}$,(iD Cemile ONAT KÖROĞLU², (iD Sevim Beyza YAMURLUKLU ${ }^{3}$, (DD Şule GÖKYILDIZ \\ SÜRÜCÜ 4
}

'Dr. Öğr. Üyesi, Çukurova Üniversitesi, Sağlık Bilimleri Fakültesi, Ebelik Bölümü, Adana, Türkiye.

${ }^{2}$ Öğr. Gör, Hatay Mustafa Kemal Üniversitesi Sağlık Bilimleri Fakültesi Hemşirelik Bölümü, Hatay, Türkiye.

${ }^{3}$ Ebe, Nevşehir Devlet Hastanesi, Nevşehir, Türkiye.

${ }^{4}$ Prof. Dr, Çukurova Üniversitesi Sağllk Bilimleri Fakültesi Ebelik Bölümü, Adana, Türkiye.

\begin{abstract}
Giriş: Gebelik öncesi doğum korkusu, genellikle doğumun tıbbileştirilmesi bağlamında tartış1lan sosyokültürel bir olgu olarak görülmektedir. Çeşitli faktörlerin sebep olduğu bu korkuyu kadınlar kadar erkeklerde deneyimleyebilir. Amaç: Çalışmanın amacı sağlık alanında eğitim alan bir grup gencin gebelik öncesi doğum korkularını etkileyen faktörleri belirlemek amacıyla yapılmıştır. Yöntem: Bu çalışma, tanımlayıcı ve kesitsel niteliktedir. Araştırmanın evreni, Türkiye'nin güneyinde bir devlet üniversitesinin Sağlık Bilimleri Fakültesi'nde kayıtlı 1. ve 4. sınıf ebelik ve hemşirelik öğrencileridir. Örneklem büyüklüğü hesaplaması ile belirlenen katılımcı sayısına göre 387 öğrenci ile çalışma yürütülmüştür. Veriler kişisel bilgi formu ve Gebelik Öncesi Doğum Korkusu Ölçeği ile toplanmıştır. Bağımlı ve bağımsız değişkenlerin karşılaştırılmasında indipendent $t$ test, one way ANOVA, bağımlı ve bağımsız değişkenlerin birbiri ile ilişkisisin belirlenmesinde ise çoklu doğrusal regresyon analizi kullanılmıştır. Bulgular: Katılımcıların yaş ortalaması $20.59 \pm 1.75$ 'tir. Gençlerin doğum korkusu ölçek toplam puan ortalaması 39.77 \pm 9.84 'tür. Katılımcıların büyük çoğunluğu vajinal doğumu tercih etmiştir. Ağrının şiddeti ile ilgili kaygılar, yetersiz baş etme becerisi, öngörülemez riskler, beden imajına yönelik kaygılar ve olumsuz doğum hikayeleri vajinal doğumu tercih edeceklerini ifade eden katılımcılar için doğum korkusunu yordayıcı faktörlerdir. Sonuç: Sağlık eğitimi almış olmalarına rağmen, gençlerin gebelik öncesi orta derecede doğum korkusu vardır. Ebeveynliğe geçmeden önce bu korkuların belirlenmesi ve çözülmesi, olumlu sağlık sonuçları için önemlidir. Danışmanlık rolleri gereği ebelik ve hemşirelik öğrencilerinin bu konudaki tutumlarının olumlu yönde geliştirilmesi için hedefli bir eğitim planlaması önerilmektedir.
\end{abstract}

Anahtar Sözcükler: Doğum Korkusu, Doğum Şekli, Doğum Tercihi, Ebe, Hemşire.

\begin{abstract}
Determine of the Factors Affecting Pre-Pregnancy Fear of Childbirth of Midwifery and Nursing Students

Background: Pre-pregnancy fear of childbirth is generally seen as a sociocultural phenomenon discussed in the context of medicalization of labor. This fear caused by various factors can be experienced by men as well as women. Objective: The aim of the study is to determine the factors affecting pre-pregnancy fears of childbirth a group of youth's enrolled in health education. Methods: This study is a descriptive and cross-sectional design. The target population of the study was 1st and 4rd class midwifery and nursing students who enrolled in a public university in the south of Turkey at the Faculty of Health Sciences. The study was conducted with 387 students according to the number of participants determined by the sample size calculation. The data were collected with personal information form and the Pre-Pregnancy Fear of Birth Scale. Indipendent $t$ test, one-way ANOVA were used to compare dependent and independent variables, and multiple linear regression analysis was used to determine the relationship between dependent and independent variables. Results: The average age of the participants is $20.59 \pm 1.75$. The mean score of the youth's fear of birth scale was $39.77 \pm 9.84$. Most of the participants stated that they would prefer vaginal delivery. Worries about the severity of pain, inadequate coping skills, unpredictable risks, concerns about body image, and negative birth stories were predictive factors for the participants who stated that they would prefer vaginal delivery. Conclusion: Although they have enrolled health education, youth's have moderate pre-pregnancy fear of childbirth. Determination and resolving this fears before step into parenthood is important for positive health outcomes. It is recommended that a purposeful teaching plan for improving the attitudes of midwifery and nursing students on this issue positively due to the necessity of consulting roles.

Key Words: Fear of Childbirth, Mode of Delivery, Birth Preference, Midwife, Nurse.
\end{abstract}

Geliş Tarihi / Received: 12.03.2021 Kabul Tarihi / Accepted: 16.09.2021

Correspondence Author: Dr. Öğr. Üyesi, Çukurova Üniversitesi, Sağlık Bilimleri Fakültesi, Ebelik Bölümü, Adana, Türkiye. Telefon: +90 05305528482 Eposta: burcuavcibay@hotmail.com

Cite This Article: Vurgeç BA, Köroğlu CO, Yamurluklu SB, Sürücü ŞG. Ebelik ve Hemşirelik Öğrencilerinin Gebelik Öncesi Doğum Korkularını Etkileyen Faktörlerin Belirlenmesi. Dokuz Eylül Üniversitesi Hemşirelik Fakültesi Elektronik Dergisi. 2021; 14(4): 413- 422 
$\mathbf{K}$ adınların gebelik, doğum ve doğum deneyimleri çok boyutludur. Bu deneyimler neşe ve doyumdan, kaygı ve dehşete kadar geniş bir aralıkta duygu durumlarını içerebilir (1). Bu duygular bireyde doğum deneyimine ilişkin olumlu ya da olumsuz algılar oluşturabilmektedir (2). Doğum algıları; doğuma yönelik duygu, düşünce ve değerlendirmeleri içeren ve kişiden kişiye farklılık gösteren algılardır. Kültürel faktörler, mitler, olumsuz deneyimler, bilgi eksikliği, sosyal destek yetersizliği, bebeğin sağlık durumu, evlilik ilişkisi, sağlı profesyonelinin yaklaşımı gibi durumlar da doğum algısını etkileyebilmektedir (3-5). Doğum algısından bahsedilirken önemli kavramlardan birisi de doğum korkusudur. Doğum korkusu, genellikle doğumun tıbbileştirilmesi bağlamında tartışılan sosyo-kültürel bir olgu olarak görülmektedir (6). Gebelerin doğumdan önce endişeli olmaları normal bir durum olarak görülse de iyilik ve sağlık halleri üzerinde etkili olabilecek doğum korkusu gelişebilmektedir. Doğum korkusu düzeyi yüksek olan bir gebe doğum süreci ile başa çıkamayacağına inanmaktadır. Eğer gebe kendi öz yeterlilik kaynaklarını harekete geçirmede yetersiz kalıyorsa, olumlu bir doğum süreci beklentisi düşük olacaktır (7). Kültürel etkiler ve bireyin doğum hakkında bilgi düzeyi bu korku üzerinde oldukça önemli bir yere sahiptir. Bireylere doğum hakkında danışmalık hizmetleri verilmesinin, doğum korkusu ve dolaylı olarak doğum algısı üzerine olumlu etkileri olabilmektedir $(8,9)$. Doğum hakkında yeterli düzeyde bilgi sahibi olmak, doğum algısını iyileştirebilmektedir. Yapılan çalışmalarda, sağlık profesyonelleri tarafından desteklenen ve bilgilendirilen gebelerin; doğum sürecini daha uyumlu geçirdiği, daha az stres yaşadığı ve baş etme becerilerinin daha iyi olduğu bildirilmektedir $(10,11)$. Bunun tam aksi durumlarda sağlık hizmeti sağlayıcılarından endişe verici bilgiler alan veya doğumla ilgili olumsuz ya da korku verici hikayelerine maruz kalan kadınlarda da doğum korkusu düzeyleri daha yüksek olduğunu belirtilen çalışmalar da mevcuttur $(12,13)$.

Kadınların yaşadığı doğum korkusu ve bu korkunun sonuçları ile ilgili birçok çalı̧̧ma olmasına rağmen (3-13), erkeklerin yaşadığı doğum korkusu daha az ele alınmaktadır $(3,12-21)$. Bu araştırmalar, baba adaylarının da tıpkı anne adayları gibi doğum korkusu yaşadığını ortaya koymaktadır. Korku, anne adaylarının yaklaşan doğumu olumsuz algılamasına ve sezaryeni tercih etmesine neden olabilmektedir. Bununla birlikte, erkeklerin tercih ettiği doğum yöntemi, hamile kadınların tercihlerini de etkilemektedir $(18,22)$. Çalışmaların bir diğer ortak özelliği genellikle gebeler ve eşleri ile yürütülmüş olmasıdır. Gençlerle yürütülmüş çalışmalar sınırlıdır $(3,4,19-23)$. Adölesan dönemde doğumdan korkan ve gebelikte doğum korkusundan muzdarip olan kadınların, epidural anestezisi olsa bile doğum sırasında dayanılmaz ağrı ve korku yaşama olasıllğının daha yüksek olduğu belirtilmektedir (24). Bu dönemdeki korku aynı zamanda uzamış doğum süresi (9) ve olumsuz bir doğum deneyimi ile de ilişkilendirilmiştir (25). Geleceğin anne ve baba adayları olan gençlerin doğum algısı, korkusu ve tercihlerine yönelik tutumlarını ile bu tutumları etkileyen faktörleri bilmek bu sebeple önemlidir. Sağlık alanında öğrenim gören veya çalışan kişilerin doğum algısı konusunda genellikle daha olumlu yaklaşım benimsedikleri düşünülmektedir. Ancak eğitimleri dışında sosyokültürel kazanımları olduğunu da unutmamak gerekir. Ebelik ve hemşirelik öğrencilerinin müfredatları kadın sağlığı ve doğum konularında yeterli eğitim içeriğine sahiptir. Bu donanımlarını kendi yaşamlarına aktaracakları gibi gelecekte danışmanlık hizmeti vermede de kullanacaklardır. Bu bakımdan ebelik ve hemşirelik öğrencilerinin doğum korkusuna yönelik tutumlarını ve bunları etkileyen faktörleri bilmek temelde bireye, uzun vadede ise sağlık sistemine ve topluma yansımalarını öngörebilmek bakımından yol gösterici olacaktır.

\section{Amaç}

Çalışmanın amacı tıbbileştirilmiş bir doğum kültürü içinde sosyalleşen sağlık alanında öğrenim gören ebelik ve hemşirelik öğrencilerinin doğuma karşı tutumlarını etkileyen faktörleri belirlemektir.

Araştırma soruları;

1. Ebelik ve hemşirelik alanında eğitim gören gençlerin gebelik öncesi doğum korkuları var mıdır?

2. Gebelik öncesinde doğuma yönelik korkular hangi faktörlerle ilişkilidir?

\section{Araştırmanın Tipi}

Araştırma tanımlayıcı ve kesitsel niteliktedir ve veriler gelişigüzel örnekleme yöntemi ile toplanmıştır.

\section{Arassturmanın Yeri ve Zamant}

Araştırma Ocak-Mart 2020 tarihleri arasında bir üniversitenin sağlı bilimleri fakültesinde gerçekleştirilmiştir.

Araştırmanın Evreni ve Örneklemi

Araştırmanın evrenini, Sağlık Bilimleri Fakültesi'nde ebelik ve hemşirelik bölümünde 1. ve 4. sınıflarda eğitim gören 554 öğrenci oluşturmaktadır ( 176 ebe, 378 hemşire). Gpower programı kullanılarak yapılan bir güç analizinde $\% 95$ güç ve alfa 0.05 ile $\mathrm{F}$ ve $\mathrm{t}$ testlerinde ortalamalar arasındaki etkileri tespit etmek için en az 305 öğrencilik bir örneklemin gerekli olacağını göstermiştir. Çoklu doğrusal regresyon modeli kullanımında 10 yordayıcının etkilerini $\% 95$ güçle tespit etmek için en az 226 öğrenciden oluşan bir örneklem gerektiğini ve kritik R2 değerinin .07 olacağını göstermiştir (H1p2:0.1). Gönüllülük esasına dayanan katılımcı uygulaması ile 134 ebe ve 253 hemşire olmak üzere toplam 387 öğrenci ile çalışma tamamlanmıştır.

Çalışmanın temel dışlama kriteri; kadınlar için daha önce doğum yapmamış olmak, erkek için ise varsa eşinin daha önce doğum yapmamış olmasıdır. Amaçlı örneklem yöntemi ile yalnızca 1 ve 4 . sınıf öğrencileri çalışmaya dahil edilmiştir. Ebelik ve hemşirelik programlarında 2. sınfftan itibaren doğum eylemi ve doğum eyleminin yönetimi konularını kapsayan dersler yer almaktadır. Alınan eğitimin doğum korkuları üzerinde etkisini etkin olarak değerlendirebilmek için konuyla ilgili dersi almış ve almamış iki sınıf düzeyi hedef örneklem grubu olarak belirlenmiştir. Veri toplama aşamasında araştırmacılar tarafından fakültede bulunan hedef sınıflarda ders sonrasında duyuru yapmıştır. Katılmaya gönüllü olan öğrencilerden dışlama kriterine uyanlar çalışmaya dahil edilmiştir. Sınıf ortamında çalışmanın amacı ve uygulama formları hakkında gerekli açıklamalar yapıldıktan sonra formlar dağıtılııştır. Katılımcılardan aydınlatılmış onam formunu isimsiz olarak imzaladıktan sonra bireysel olarak formları doldurmaları istenmiştir. 


\section{Veri Toplama Araçlart}

Veriler, literatür doğrultusunda araştırmacılar tarafından özgün olarak hazırlanmış tanıtıcı bilgi formu ve genç kadın ve erkeklerin gebelik öncesi doğum korkusunu ölçme aracı olarak geliştirilmiş Gebelik Öncesi Doğum Korkusu Ölçeği kadın ve erkek versiyonları kullanılmıştır.

Tanıtıcı bilgi formu; çalışmanın ilk bölümünde yer alan ve araştırmacılar tarafından literatür doğrultusunda özgün olarak hazırlanmıştır. Öğrencilerin sosyo-demografik özellikleri, doğum tercihleri ve doğum sürecine ilişkin tutumlarını belirlemeye yönelik 15 sorudan oluşmaktadır.

Gebelik Öncesi Doğum Korkusu Ölçeği; Stoll ve ark. (19) tarafından geliştirilmiş, ölçeğin Türkçe' ye uyarlamasının geçerlik ve güvenirlik çalışması Uçar ve Taşhan (20) tarafından yapılmıştır. Ölçeğin, kadın ve erkek olmak üzere iki versiyonu vardır. Ölçek genç kadın ve erkeklerin doğum korkusuna en çok neden olan doğum ağrısı, kontrol kaybı, doğum ağrısı ve doğumla baş edememe, komplikasyonlar ve geri donuşumu olmayan fiziksel hasarlar boyutlarını içermektedir. Kadınlar için hazırlanan Kadın Gebelik Öncesi Doğum Korkusu Ölçeği (KGÖ-DKÖ) ve erkekler için hazırlanan Erkek Gebelik Öncesi Doğum Korkusu Ölçeğinin (EGÖ-DKÖ) her biri 6’lı likert tipte 10 maddeden oluşmaktadır. Ölçekten alınabilecek en düşük puan 10 , en yükssek puan ise $60^{\prime}$ tır. Tersine puanlaması olmayan ölçeğin toplam puanın yükssek olması yüksek düzeyde korkuyu göstermektedir. Ölçeği geliştiren Stoll ve arkadaşları (2016) da ölçeğin Cronbach's alfa iç tutarlık kat sayısını kadın ve erkekler için ayrı ayrı değerlendirmiş ve ve sırasıyla $.81-.89$ olduğunu belirtmiştir. Uçar ve Taşhan (2018) araştırmasında KGÖ-DKÖ'nun cronbach's alfa iç tutarlık kat sayısının 0.89, EGÖ- DKÖ'nun cronbach's alfa iç tutarlık kat sayısının .84 olduğunu belirlemiştir. Çalışmamızda ölçeğin cronbach alfa iç tutarlık kat sayısının KGÖ- DKÖ için .88 ve EGÖ- DKÖ için .85 olarak belirlenmiştir.

\section{Verilerin Analizi}

Veriler Statistical Programme for Social Science 20.0 (SPSS) tanımlayıcı ve parametrik istatistiksel analiz yöntemleri kullanılarak analiz edilmiştir. İlk olarak öğrencilerin tanıtıcı özellikleri, sosyo-demografik özellikleri, doğum tercihleri ve doğum sürecine ilişkin tutumlarını tanımlayıcı analizler yapılmıştır. Bu analizler frekans ve yüzde olarak, toplam ve kadın-erkek kategorilerinde belirlenmiştir. Bağımlı ve bağımsız değişkenlerin karşılaştırılmasında 2 grup ortalamaları arasındaki farkı değerlendirirken Indipendent $t$ test, 3 veya daha fazla sayıda grubun ortalamaları arasındaki farkı değerlendirirken One way ANOVA testi kullanılmıştır. Bağımlı ve bağımsız değişkenlerin birbiri ile ilişkisisin belirlenmesinde Çoklu Doğrusal Regresyon analizi kullanılmıştır. Regresyon analizi sonuçları, regresyon katsayısı ( $\beta$ ), belirlilik katsayısı (R / R2), model uyum iyiliği ( $F$ / $t$ ve p) ve \%95 güven aralığı değerleri ile gösterilmiştir. İstatistiksel anlamlılık değeri olarak .005 dikkate alınmıştır.

\section{Araştırmanin Etik Yönü}

Araştırmanın yürütüldüğü üniversitenin Girişimsel Olmayan Klinik Araştırmalar Etik Kurulu'ndan onay alınmıştır (Onay tarih/no:10.01.2020/95-51). Etik kurul onayı alınan çalışmanın uygulama aşaması için Sağlık Bilimleri Fakültesinden çalışma izni alınmıştır. Araştırmada kullanılan ölçeğin kullanım izni, geçerlilik güvenirliğini yapan yazarlar tarafindan açık erişime sunulmuştur. Çalışmanın gönüllü, istendiği zaman sonlanabilen ve isimsiz niteliği hem sözlü hem de aydınlatılmış onam bölümünde yazılı olarak katılımcılara belirtilmiştir. Çalışmanın her aşamasında araştırma ve yayın etiğine uyulmuştur.

\section{Bulgular}

Çalışmaya katılan öğrencilerin tümü bekardır ve yaş ortalaması $20.59 \pm 1.75$ 'tir. Öğrencilerin yarısından fazlası şehir merkezinde yaşadıklarını (\%59.7), \%33.3'ü gelir düzeyinin orta olduğunu ve \%80.4'ü çekirdek aileye sahip olduğunu belirtmiştir. Yaş, gelir düzeyi yaşanılan yer, aile yapısı bakımından cinsiyetler arasında anlamlı fark yoktur. Kadınların \%85.2'si kendileri, erkeklerin ise \%89.1'i eşleri için vajinal doğumu tercih edeceklerini belirtmiştir. Anne doğum şekli \%85.5'inde vajinal doğum olarak belirtilmiştir. Cinsiyetler arasında doğum tercihleri ve annenin doğum şekli bakımından anlamlı fark olmadığı belirlenmiştir (Tablo 1). 
Tablo 1. Katılimcıların Tanıtıcı Özellikleri

\begin{tabular}{|c|c|c|c|c|}
\hline Özellikler & & $\begin{array}{c}\text { Toplam(n:387) } \\
\mathbf{n}(\%)\end{array}$ & $\begin{array}{c}\operatorname{Kadın}(\mathbf{n}: 332) \\
\mathbf{n}(\%)\end{array}$ & $\begin{array}{c}\text { Erkek(n:55) } \\
\text { n(\%) }\end{array}$ \\
\hline \multirow[t]{2}{*}{ Yaş } & $\leq 20$ & 191(49.4) & $171(51.5)$ & $20(36.4)$ \\
\hline & $20 \uparrow$ & 196(50.6) & $161(48.5)$ & $35(63.6)$ \\
\hline \multirow[t]{2}{*}{ Bölüm } & Ebelik & $134(34.6)$ & $134(40.4)$ & - \\
\hline & Hemşirelik & $253(65.4)$ & $198(59.6)$ & $55(100)$ \\
\hline \multirow[t]{2}{*}{ Sinif } & 1 & $210(54.3)$ & $182(54.8)$ & $28(50.9)$ \\
\hline & 4 & $177(45.7)$ & $150(45.2)$ & 27(49.1) \\
\hline \multirow{3}{*}{ Yaşanılan yer } & İl & 231(59.7) & 197(59.3) & $34(61.8)$ \\
\hline & İlçe & $105(27.1)$ & $92(27.7)$ & $13(23.6)$ \\
\hline & Kasaba & $51(13.2)$ & $43(13.0)$ & $8(14.5)$ \\
\hline \multirow{4}{*}{ Gelir düzeyi algısı } & Gelir giderden oldukça az & $118(30.5)$ & $99(29.8)$ & $19(34.5)$ \\
\hline & Gelir giderden az & $96(24.8)$ & $82(24.7)$ & $14(25.5)$ \\
\hline & Gelir gidere denk & $129(33.3)$ & $115(34.6)$ & $14(25.5)$ \\
\hline & Gelir giderden fazla & $44(11.4)$ & $36(10.8)$ & $8(14.5)$ \\
\hline \multirow{3}{*}{ Aile tipi } & Çekirdek & $311(80.4)$ & $270(81.3)$ & $41(74.5)$ \\
\hline & Geniş & $62(16.0)$ & $52(15.7)$ & $10(18.2)$ \\
\hline & Dağılmış & $14(3.6)$ & $10(3.0)$ & $4(7.3)$ \\
\hline \multirow[t]{2}{*}{ Doğum şekli tercihi } & Vajinal & $332(85.8)$ & $283(85.2)$ & $49(89.1)$ \\
\hline & Sezaryen & $55(14.2)$ & $49(14.8)$ & $6(10.9)$ \\
\hline \multirow[t]{2}{*}{ Anne doğum şekli } & Vajinal & $331(85.5)$ & $283(85.2)$ & $48(87.3)$ \\
\hline & Sezaryen & $56(14.5)$ & $49(14.8)$ & $7(12.7)$ \\
\hline
\end{tabular}

KDÖ-DKÖ ortalaması $40.58 \pm 9.61$ ve EDÖ-DKÖ ortalaması $34.89 \pm 9.88^{\prime}$ dir. Kadınların doğum korkusu daha fazladır ve cinsiyetlere göre ölçek puan ortalamaları arasındaki bu fark anlamlıdır $(t=4.047, p=.001)$. Sınıf düzeyinin ve sosyo-demografik özelliklerin hem tüm grupta hem de cinsiyetler arasında anlamlı bir fark yaratmadığı belirlenmiştir $(\mathrm{p}=.128)$. Tablo 2'de öğrencilerin gelecekteki doğum şekli tercihlerini etkisi olabilecek faktörler ve ölçek puanları ile karşılaştırmaları yer almaktadır. Kadınlar için yalnızca cinsel yaşam ile ilgili endişelerin doğum korkusuna yönelik anlamlı bir fark yaratmadığı belirlenmiştir. Bunun dışında doğum ağrısı, yetersiz baş etme becerisi, bedende oluşabilecek fiziksel hasarlar, öngörülemez riskler, yenidoğanla ilgili endişeler, doğuma ilişkin dinlenmiş kötü öyküler ve beden imajı ile ilgili kaygıların artı̧ı durumunda doğum korkusu ölçek puanlarının anlamlı düzeyde yükseldiği belirlenmiştir. Erkeklerde ise eşinin bedende oluşabilecek fiziksel hasarlar ve eşinin beden imajı ile ilgili kaygıların artması durumunda doğum korkusu ölçek puanlarının anlamlı düzeyde yükseldiği belirlenmiştir. 
Tablo 2. Vajinal Doğum Tercihine Etki Edebilecek Çeşitli Değişkenler ile DKÖ Puan Ortalamalarının Karşılaştırması (n:387)

\begin{tabular}{|c|c|c|c|c|c|c|}
\hline \multirow[b]{2}{*}{ Değişkenler } & & \multicolumn{2}{|c|}{ Kadın } & \multicolumn{2}{|c|}{ Erkek } & \multirow[b]{2}{*}{$p^{*}$} \\
\hline & & n (\%) & KDÖ-DKÖ & n (\%) & EDÖ-DKÖ & \\
\hline \multirow[t]{2}{*}{ Doğum ağrısının şiddeti } & Evet & $160(48.2)$ & $43.78 \pm 8.51$ & $12(21.8)$ & $37.08 \pm 9.85$ & $p^{k}=.000$ \\
\hline & $\begin{array}{l}\text { Hayı } \\
\mathrm{r}\end{array}$ & $172(51.8)$ & $37.60 \pm 9.65$ & $43(78.2)$ & $34.28 \pm 9.92$ & $p^{e}=.390$ \\
\hline \multirow[t]{2}{*}{ Yetersiz baş etme becerisi } & Evet & $108(32.5)$ & $43.76 \pm 7.88$ & $8(14.5)$ & $39.13 \pm$ & $p^{k}=.000$ \\
\hline & $\begin{array}{l}\text { Hayı } \\
\mathrm{r}\end{array}$ & $224(67.5)$ & $\begin{array}{l}39.05 \pm \\
10.01\end{array}$ & $47(85.5)$ & $\begin{array}{l}11.61 \\
34.17 \pm 9.51\end{array}$ & $p^{e}=.193$ \\
\hline $\begin{array}{l}\text { Doğumun bedenimde/eşimin } \\
\text { bedende oluşturacağ fiziksel } \\
\text { etkilerin olması }\end{array}$ & $\begin{array}{l}\text { Evet } \\
\text { Hayı } \\
\mathrm{r}\end{array}$ & $\begin{array}{c}99(29.8) \\
233(70.2)\end{array}$ & $\begin{array}{l}43.57 \pm 8.81 \\
39.31 \pm 9.68\end{array}$ & $\begin{array}{c}8(14.5) \\
47(85.5)\end{array}$ & $\begin{array}{l}44.25 \pm \\
10.83 \\
33.30 \pm 8.89 \\
\end{array}$ & $\begin{aligned} p^{k} & =.000 \\
p^{e} & =.003\end{aligned}$ \\
\hline Öngörülemez riskler & $\begin{array}{l}\text { Evet } \\
\text { Hayı } \\
\mathrm{r}\end{array}$ & $\begin{array}{c}75(22.6) \\
257(77.4)\end{array}$ & $\begin{array}{l}43.96 \pm 7.14 \\
39.60 \pm \\
10.02 \\
\end{array}$ & $\begin{array}{c}4(7.3) \\
51(92.7)\end{array}$ & $\begin{array}{l}42.50 \pm 5.44 \\
34.29 \pm 9.9\end{array}$ & $\begin{array}{l}p^{k}=.000 \\
p^{e}=.111\end{array}$ \\
\hline Fetus/yenidoğan ile ilgili endişeler & $\begin{array}{l}\text { Evet } \\
\text { Hayı } \\
\mathrm{r}\end{array}$ & $\begin{array}{l}109(32.8) \\
223(67.2)\end{array}$ & $\begin{array}{l}42.98 \pm 8.92 \\
39.41 \pm 9.70\end{array}$ & $\begin{array}{l}12(21.8) \\
43(78.2)\end{array}$ & $\begin{array}{l}38.58 \pm 9.77 \\
33.86 \pm 9.78\end{array}$ & $\begin{array}{l}p^{k}=.000 \\
p^{e}=.145\end{array}$ \\
\hline Doğuma ilişkin kötü öyküler & $\begin{array}{l}\text { Evet } \\
\text { Hayı } \\
\mathrm{r}\end{array}$ & $\begin{array}{c}302(91.0) \\
30(9.0)\end{array}$ & $\begin{array}{l}40.87 \pm 9.34 \\
36.05 \pm \\
12.60 \\
\end{array}$ & $\begin{array}{l}42(76.4) \\
13(23.6)\end{array}$ & $\begin{array}{l}34.55 \pm 9.73 \\
36.00 \pm \\
10.68 \\
\end{array}$ & $\begin{array}{l}p^{k}=\mathbf{0 3 0} \\
p^{e}=.648\end{array}$ \\
\hline Beden imajı ile ilgili kayg1 & $\begin{array}{l}\text { Evet } \\
\text { Hayı } \\
\mathrm{r}\end{array}$ & $\begin{array}{l}190(57.2) \\
142(42.8)\end{array}$ & $\begin{array}{l}45.28 \pm 7.33 \\
34.30 \pm 8.69\end{array}$ & $\begin{array}{l}17(30.9) \\
38(69.1)\end{array}$ & $\begin{array}{l}43.00 \pm 7.77 \\
31.26 \pm 8.53\end{array}$ & $\begin{array}{l}p^{k}=.001 \\
p^{e}=.001\end{array}$ \\
\hline Cinsel yaşam ile ilgili endişeler & $\begin{array}{l}\text { Evet } \\
\text { Hayı } \\
\text { r }\end{array}$ & $\begin{array}{l}125(37.7) \\
207(62.3)\end{array}$ & $\begin{array}{l}40.28 \pm \\
10.06 \\
40.76 \pm 9.36\end{array}$ & $\begin{array}{l}15(27.3) \\
40(72.7)\end{array}$ & $\begin{array}{l}38.40 \pm 8.83 \\
33.58 \pm \\
10.04\end{array}$ & $\begin{array}{l}p^{k}=.639 \\
p^{e}=.140\end{array}$ \\
\hline
\end{tabular}

*Indipendent $t$ test, $\mathrm{p}^{\mathrm{k}}$ : KDÖ-DKÖ, $\mathrm{p}^{\mathrm{e}}$ : EDÖ-DKÖ

Doğum şekli tercihine etki edebilecek çeşitli değişkenler ile doğum korkusu arasındaki ilişki, çoklu doğrusal regresyon modeli ile incelenmiştir (Tablo 3). Tercih edilen doğum şekline göre model analizlerinde model uyum iyiliği $(\mathrm{F} / \mathrm{p})$ regresyon katsayıları (R/R2) değerlendirmesinde anlamlı bir model olduğu görülmüştür. Modele göre vajinal ve sezaryen doğum tercihlerine göre doğuma yönelik korkuları yordayıcı faktörlerin değişiklik gösterdiği belirlenmiştir. Ağrının şiddeti ile ilgili kaygılar, yetersiz baş etme becerisi, öngörülemez riskler olabileceği düşüncesi, beden imajına yönelik kaygılar ve dinlenmiş olumsuz doğum hikayeleri vajinal doğumu tercih edeceklerini ifade eden katılımcılar için doğum korkusunu yordayıcı faktörlerdir. Bu değişkenlerin bireylerin tercihi üzerindeki etkisi arttıkça vajinal doğuma ilişki korku düzeylerinde artış olduğu görülmektedir. Doğum şekli olarak sezaryen tercihinde bulunanların bedende oluşturabileceği fiziksel etkiler ve beden imajı ile ilgili kaygılarının artması doğuma yönelik korkuların artmasının anlamlı yordayıcılarıdır. 
Tablo 3. Doğum Korkusunu Yordayıcı Faktörlerin Doğum Şekli Tercihine Göre Çoklu Doğrusal Regresyon Analizi Modeli

\begin{tabular}{|c|c|c|c|c|c|c|c|c|}
\hline \multirow{2}{*}{\multicolumn{2}{|c|}{ Doğum şekli Değişkenler }} & \multirow[b]{2}{*}{ B } & \multirow[b]{2}{*}{$\beta$} & \multirow[b]{2}{*}{$t$} & \multirow[b]{2}{*}{$p$} & \multicolumn{2}{|c|}{$\% 95$ CI } & \multirow[b]{2}{*}{ Model Uyumu } \\
\hline & & & & & & Lower & Upper & \\
\hline \multirow{8}{*}{ Vajinal } & Ağr1 & 4.284 & 0.222 & 3.801 & .000 & 6.501 & 2.067 & \multirow{8}{*}{$\begin{array}{l}R=.57 \\
R^{2}=.32 \\
F=53.100\end{array}$} \\
\hline & Baş etme becerisi & 2.325 & 0.112 & 1.881 & .041 & 4.758 & 0.107 & \\
\hline & Fiziksel etkiler & 1.617 & 0.075 & 1.360 & .175 & 3.956 & 0.722 & \\
\hline & $\underline{\text { Öngörülemez riskler }}$ & 4.465 & 0.190 & 3.459 & .001 & 7.004 & 1.925 & \\
\hline & $\begin{array}{l}\text { Yenidoğanla ilgili } \\
\text { endişeler }\end{array}$ & 0.604 & 0.030 & 0.506 & .613 & 1.742 & 2.950 & \\
\hline & Beden_imaj1 & 10.693 & 0.560 & 12.371 & .000 & 12.393 & 8.993 & \\
\hline & Cinsel_yaşam & 0.431 & 0.022 & 0.481 & .631 & 2.195 & 1.333 & \\
\hline & Kötü_öykü & 3.695 & 0.111 & 2.451 & .015 & 6.661 & 0.729 & \\
\hline \multirow{8}{*}{ Sezaryen } & Ağr1 & 3.675 & 0.188 & 1.318 & .194 & 9.281 & 1.930 & \multirow{8}{*}{$\begin{array}{l}R=.61 \\
R^{2}=.37 \\
F=10.162\end{array}$} \\
\hline & Baş etme becerisi & 3.897 & 0.174 & 1.109 & .273 & 3.167 & 10.962 & \\
\hline & Fiziksel etkiler & 5.997 & 0.293 & 2.122 & .039 & 11.678 & 0.317 & \\
\hline & Öngörülemez riskler & 1.815 & 0.072 & 0.559 & .579 & 4.713 & 8.344 & \\
\hline & $\begin{array}{l}\text { Yenidoğanla ilgili } \\
\text { endişeler }\end{array}$ & 6.373 & 0.292 & 1.791 & .079 & 13.523 & 0.776 & \\
\hline & Beden_imaj1 & 13.347 & 0.610 & 5.379 & .000 & 18.328 & 8.366 & \\
\hline & Cinsel_yaşam & 1.609 & 0.078 & 0.689 & .494 & 6.296 & 3.077 & \\
\hline & Kötü_öykü & 2.208 & 0.051 & 0.449 & .656 & 7.670 & 12.086 & \\
\hline
\end{tabular}

Doğum şekli tercihine etki edebilecek çeşitli değişkenler ile doğum korkusu arasındaki ilişki, çoklu doğrusal regresyon modeli ile incelenmiştir (Tablo 4). Cinsiyete göre model analizlerinde model uyum iyiliği (F/p) regresyon katsayıları (R/R2) değerlendirmesinde anlamlı bir model olduğu görülmüştür. Modele göre kadın ve erkeklerin doğuma yönelik korkularını yordayan faktörlerin değişiklik gösterdiği belirlenmiş̧ir. Ağrının şiddeti ile ilgili kaygılar, öngörülemez riskler olabileceği düşüncesi, beden imajına yönelik kaygılar ve dinlenmiş olumsuz doğum hikayeleri kadınların doğum korkusunu yordayıcı faktörlerdir. Erkeklerin ise eşinin beden imajı ve cinsel yaşama yönelik kaygıları doğuma yönelik korkuların artmasının anlamlı yordayıcılarıdır.

Tablo 4. Doğum Korkusunu Yordayıcı Faktörlerin Cinsiyete Göre Çoklu Doğrusal Regresyon Analizi Modeli

\begin{tabular}{|c|c|c|c|c|c|c|c|c|}
\hline \multirow[b]{2}{*}{ Cinsiyet } & \multirow[b]{2}{*}{ Değişkenler } & \multirow[b]{2}{*}{ B } & \multirow[b]{2}{*}{$\beta$} & \multirow[b]{2}{*}{$\mathbf{t}$} & \multirow[b]{2}{*}{$\mathbf{p}$} & \multicolumn{2}{|c|}{$\% 95 \mathrm{CI}$} & \multirow[b]{2}{*}{ Model Uyumu } \\
\hline & & & & & & Lower & Upper & \\
\hline \multirow{8}{*}{ Kadın } & Ağr1 & 3.740 & 0.195 & 3.976 & .000 & 5.590 & 1.889 & \multirow{8}{*}{$\begin{array}{l}R=.63 \\
R^{2}=.40 \\
F=27.696\end{array}$} \\
\hline & Baş etme becerisi & 1.079 & 0.053 & 1.054 & .292 & 3.094 & 0.935 & \\
\hline & Fiziksel etkiler & 0.711 & 0.034 & 0.716 & .475 & 1.244 & 2.667 & \\
\hline & Öngörülemez riskler & 3.034 & 0.132 & 2.911 & .004 & 5.084 & 0.983 & \\
\hline & $\begin{array}{l}\text { Yenidoğanla ilgili } \\
\text { endişeler }\end{array}$ & 0.342 & 0.017 & 0.339 & .735 & 2.330 & 1.646 & \\
\hline & Beden_imaj1 & 10.307 & 0.531 & 11.787 & .000 & 12.027 & 8.586 & \\
\hline & Cinsel_yaşam & 0.187 & 0.009 & 0.217 & .828 & 1.885 & 1.510 & \\
\hline & Kötü_öykü & 3.705 & 0.092 & 2.115 & .035 & 7.151 & 0.259 & \\
\hline \multirow{8}{*}{ Erkek } & Ağr1 & 2.023 & 0.085 & 0.618 & .540 & 8.615 & 4.569 & \multirow{8}{*}{$\begin{array}{l}R=.66 \\
R^{2}=.43 \\
F=4.474\end{array}$} \\
\hline & Baş etme becerisi & 0.680 & 0.024 & 0.153 & .879 & 9.644 & 8.284 & \\
\hline & Fiziksel etkiler & 6.624 & 0.238 & 1.559 & .126 & 15.179 & 1.931 & \\
\hline & Öngörülemez riskler & 5.161 & 0.137 & 0.976 & .334 & 5.488 & 15.809 & \\
\hline & $\begin{array}{l}\text { Yenidoğanla ilgili } \\
\text { endişeler }\end{array}$ & 1.475 & 0.062 & 0.434 & .666 & 8.316 & 5.366 & \\
\hline & Beden_imaj1 & 10.841 & 0.511 & 4.222 & .000 & 16.010 & 5.672 & \\
\hline & Cinsel_yaşam & 5.754 & 0.262 & 2.198 & .033 & 11.022 & 0.485 & \\
\hline & Kötü_öykü & 2.245 & 0.097 & 0.847 & .402 & 3.092 & 7.582 & \\
\hline
\end{tabular}

\section{Tartışma}

Doğum algıları kişiler ve kültürler arasında farklılık gösteren bir durumdur. Olumsuz doğum algısı ile ilişkilendirilen doğum korkusu, genellikle gebelikten önce başlayan ve kadın-erkek fark etmeksizin bireyleri etkileyen bir kavramdır $(3,4,9,15-19)$. Literatürde, doğum korkusunu belirlemek için gebelik öncesi doğum korkusu ölçeği kullanılarak yapılan çalışmalar incelendiğinde; Hildingsson ve ark.'nın (21) doğurganlık çağındaki kadınlarla yaptıkları çalışmada katılımcıların ölçek toplam puan ortalamasının $38.42 \pm 28.49$ olduğu, Swift ve ark. (26) ise kadın üniversite öğrencileri ile yaptıkları çalışmada ölçek toplam puan ortalamasının $35.76 \pm 9.53$ olduğu bildirilmektedir. Stoll ve ark.'nın (3) 
üniversite öğrencileri ile yaptıkları çalışmada ortalama doğum korkusu puanı 18.37 iken kadınlarda 18.60, erkelerde 17.20'dir. Çalışmamızda kadınların doğum korkusu ölçek toplam puan ortalaması 40.58, erkeklerin ise 37.84' dir. Bu sonuçlar doğuma yönelik korkuların hamilelikten önce var olduğunu destekler niteliktedir. Diğer taraftan İsveç (21) ve İzlanda (26) popülasyonuna benzer sonuçlara sahip bulgularımız, Kanada popülasyonu (3) bulgularının ise oldukça üzerindedir. Stoll ve ark. (3) bu sonucu gebelik öncesi doğum korkusunun hedefli eğitim programları aracılı̆̆ıla değiştirilebileceğinin bir göstergesi olarak yorumlamıştır. Literatüre benzer bir diğer benzer sonucumuz ise kadınların erkeklerden daha yüksek düzeyde doğum korkusuna sahip olmasıdır.

Doğum korkusu, doğum tercihini etkileyen en önemli faktörlerden biridir. Bu sebeple doğum korkusunun özellikle de gençlik döneminde değerlendirilmesi büyük önem taşımaktadır. Kadınların öz yeterliklerini güçlendirmek olumlu doğum deneyimleri kazandırabilmesi yanında uzun vadede sezaryen sayısını azaltma potansiyeline de sahiptir (7). Hauck et al. (27) yaptıkları çalışmada, Avustralyalı genç kadınların \%84.4'ünün vajinal doğumu tercih ettiği bildirilmektedir. Kadınların vajinal doğum tercihi olarak en fazla bildirdikleri üç sebep sırasıyla; doğum için normal bir yol olması (\%78.3), cerrahi işlemden kaçınma/korkma (\%53.4), iyileşmenin ve ağrının daha az olması (\%53.1) şeklindedir. Swift et al. (26) yaptıkları çalışmada İzlandalı kadınların \%89.9'unun vajinal doğumu tercih ettiği bildirilmektedir. Kadınların vajinal doğum tercihi olarak en fazla bildirdikleri üç sebep sırasıyla; doğum için normal bir yol olması (\%80.9), cerrahi işlemden kaçınma/korkma (\%44.3), daha az komplikasyon (\%31.5) şeklindedir. Çalışmamızda ise kadınların \%85.2'si erkeklerin ise \%89.1'i vajinal doğumu tercih ettikleri belirlenmiştir. Her iki cinsiyette de vajinal tercihi olarak belirtilen ilk üç sebep sırasıyla sağlıklı olması, iyileşmenin daha hızlı olması ve doğal bir yol olmasıdır. Bu oranlar anne doğum şekli ile benzerdir. Sınıf düzeyleri arasında anlamlı bir fark bulunmadığı için bu durumun eğitimle değil kültürle ilişkili olduğunu düşünülmektedir.

Bilgin (23) yaptığı nitel çalışmada, genç hemşire adayları olan kadınların büyük çoğunluğunun normal doğumu tercih ettiği bildirilmektedir. Gençlerin doğum tercihini belirleyen en büyük etkenin ise fiziksel iyi oluş hali olduğu ifade edilmektedir. Genç kadınların doğuma ilişkin olumsuz görüşlerinin çoğunlukla acı-zorluk, korku-endişe ve ağrısancı üzerine odaklandığı ifade edilmektedir. Stoll et al. (3) yaptıkları çalışmada, kadınların \% $\% .8$, erkeklerin ise \%8.4'ünün sezaryen doğumu tercih ettiği belirtilmektedir. Gebelik ve doğumla ilişkili fiziksel değişikliklere yönelik endişeler, gençlerin doğum tercihini etkilemektedir. Bedenleri üzerindeki değişiklikten endişe duyan genç kadınların sezaryeni tercih etme olasılıklarının dört kat daha yüksek olduğu vurgulanmaktadır. Saroli-Palumboetal et al. (28) yaptığı çalışmada, genç kadınların \%19.1'inin erkeklerin ise \%22.2'sinin vajinal doğuma kıyasla sezaryen doğumun cinsel sorunları önlediği görüşünde oldukları bildirilmektedir. Kapısız ve ark. (4), yaptığı çalışmada, genç hemşire adaylarının doğum korkularının genellikle vajinal doğuma ilişkin olduğu belirtilmiştir. Öğrencilerin doğumdan korkma sebepleri ise; vajinal doğum sırasında bebeğin veya kendisinin/eşinin zarar göreceğine dair kayg1, vajinal doğum için yeterli güç ve beceriye sahip olmadığını düşünme, doğum anındaki ağrıdan, yalnız kalmaktan ve doğum sonrası bedensel değişimlerden korkma şeklindedir. Öğrenciler, eğitimleri sırasında aldıkları doğum ve kadın sağlığı ile ilgili derslerin, doğuma yönelik korkularını daha fazla artırdığını ifade etmektedir. Eğitimin doğum korkusu üzerine etkisini ölçebilmek için farklı sınıf düzeylerini dahil ettiğimiz çalışma bulgularımızda ise sınıflar arasında anlamlı bir fark bulunmamıştır. Bu sonuç olumsuz etkilenmemiş olmamaları bakımından sevindirici iken kazanılmış ya da kalıplaşmış düşünce sistemlerini değiştirmede yetersiz olması bakımından düşündürücüdür.

Kadıŏlu ve Şahin (29)'nin, genç kadınlar ile gerçekleştirdiği çalışmada, kadınların \%73.5'inin sezaryen doğumu tercih ettiği bildirilmektedir. Sağlık alanın eğitim görenler ile diğer alanlarda eğitim alanların doğum tercihleri birbirine benzerdir. Stoll ve ark. (3) öğrencilerin üçte biri sezaryen ameliyatı konusunda endişeli olmadığını ve sezaryeni tercih etme olasılıklarının daha yüksek olduğunu belirtmektedir. Haines ve ark. (30) Avustralyalı ve İ́sveçli gebelerle yaptıkları çalışmada, doğumdan korkan kadınların gebelik sırasında 3.3 kat daha fazla sezaryene yöneldikleri ve elektif sezaryen olma olasılıklarının 5.4 kat arttığını belirtmişlerdir. Bulgularımızda gençlerin \%85.8'inin vajinal doğum, \%14.2'sinin sezaryen doğumu tercih ettiği belirlenmiştir. Her iki cinsiyette de gençlerin tercihi yüksek oranda vajinal doğum olmuştur. Çalışmamızdaki gençlerin annelerinin doğum şekli ile kendi doğum şekli tercihleri büyük oranda birbiri ile örtüşmekte olup, büyük çoğunluğu annesi gibi normal doğum yapmayı tercih ettiğini belirtmiştir. Bu bağlamda, annelerin doğum deneyimlerinin, gençlerin doğum tercihleri üzerinde belirleyici bir etkiye sahip olduğu söylenebilir.

Bulgularımızda vajinal doğum tercih edenlerin doğum korkularını etkileyen yordayıcıların sayısı sezaryeni tercih edenlerinkinden fazladır. Kadınlarda doğum şekli tercihini en fazla etkileyen üç değişken sırasıyla; doğuma ilişkin öyküler, beden imajı ve doğum ağrısı ile ilgili kaygılar olmuştur. Erkeklerde ise bu değişkenler; doğuma ilişkin öyküler, beden imajı ve cinsel yaşam ile ilgili kaygılar şeklinde sıralanmıştır. Doğuma ilişkin olumsuz öyküler ve doğum ağrısına yönelik endişeler korkuyu etkileyen en yaygın obstetrik faktörlerdir (3, 15-21, 29, 30). Stoll et al. (3) yaptıkları çalışmada, genç kadınların doğum korkusu düzeyini düşük ve yüksek doğum korkusu şeklinde ele almaktadır. Düşük düzeyde doğum korkusuna sahip olan kadınların; ağrı, kötü doğum öyküleri, komplikasyonlar ve obstetrik müdahalelerden etkilendiği vurgulanmaktadır. Yüksek düzeyde doğum korkusu olan kadınların ise doğum ağrısı ve vajinal yaralanmalardan kaçınmak için sezaryen doğuma yöneldiği bildirilmektedir.

Gebelik sırasında kadın vücudundaki fiziksel değişiklikler ve beden imajı üzerindeki etkileri hem kadın hem de erkekler için doğum korkusunu yordayıcı faktörler olarak belirlenmiştir. Gebe ve gebe olmayana kadınlarda doğum korkusu üzerinde etkili ortak bir faktör olduğunu belirten çalışmalar mevcuttur (30-32). Doğuma yönelik tutum ve inançların doğal olarak kadın güzelliğinin sosyal yapılarıyla bağlantılı olabileceğini ve beden imajı ile ilgili memnuniyetin doğum korkusu ile negatif yönde ilişkili olduğu ifade edilmektedir (31). Sonuçlarımız bu bulguları destekler niteliktedir. Beden imajı, hem doğum şekline göre hem de cinsiyete göre doğum korkusunu yordayan faktörlerdendir. 
Cinsellik ile ilgili endişeler hem kadını hem de erkeği elektif sezaryen olmaya yönlendirebilmektedir. Vajinal doğumların gelecekteki cinselliklerine zararlı olduğuna inanan bireylerin sezaryen doğumu tercih etme olasıllğının daha yüksek olabileceğini belirtilmektedir (33, 34). Stützer ve ark. (33) çalışmalarında doğumla ilgili vajinal değişiklikler nedeniyle cinselliğin bozulacağı ve partnerinin vulvayı daha az çekici bulacağından korkmanın elektif sezaryen kararını etkileyen faktörlerden olduğu belirtilmiştir. Spaich ve ark. (34) çalışma bulgularında bazı kadınların sezaryen ile doğumu, vajinanın bütünlüğünü korumanın ve dolayısıyla cinselliklerini korumanın bir yolu olarak gördüklerini ve bu görüşleri destekleyen kadınların çoğunun sezaryenle doğum yapmayı tercih ettiklerini belirlemişlerdir. Çalışmamızda kadınların doğum korkularını etkileyen bir faktör olarak görülmeyen cinsel yaşam, erkelerin doğum korkuları üzerinde etkili bir yordayıcıdır. Bugüne kadar yapılan araştırmaların çoğunun vajinal doğum yapmanın kişinin sonraki cinsel yaşamına zararlı olduğu veya sezaryenle doğum yapmanın koruyucu olduğu iddialarını desteklemediği göz önüne alındığında, çeşitli kaynaklardan iletilen yanlış bilgilerin ortadan kaldırılması sadece kadınlar değil erkekler bakımından da önemlidir.

\section{Sonuçların Uygulamada Kullanımı}

Çalışmamıza katılan gençlerin büyük çoğunluğunun ilerde kendisi veya eşi için normal doğumu tercih ettiği belirlenmiştir. Orta düzeyde doğum korkusuna sahip olmakla birlikte ağrı, baş etme becerileri, öngörülmez riskler, kötü öyküler, fiziksel etkiler, cinsel yaşam ve beden imajına yönelik endişelerin gençlerin doğum şekli tercihini ve doğum korkusunu etkileyen faktörlerdir. Geleceğin anne ve baba adayı olan gençlerin doğuma ilişkin korkularının, ebeveynliğe adım atmadan önce belirlenip çözüm odaklı yaklaşımlar geliştirilmesi için bu tür çalışmaların özellikle gençler ile yürütülmesi önerilmektedir. Bir diğer önemli çıkarım ise özellikle danışmanlık rolleri gereği ebelik ve hemşirelik öğrencilerinin bu konudaki tutumlarının olumlu yönde geliştirilmesinin önemli bir halk sağlığı sorumluluğu olmasıdır. Doğum konusunda korkuları olan sağlık profesyonelleri danışanların kaygılarını giderme de yetersiz kalabilir ya da kendi duygularını aktarma yönünde bir eğilim gösterebilirler. Bu sebeple hem bireysel hem de toplumsal açıdan olumlu kazanımlar sağlamak için hedefli bir eğitim planlaması önerilmektedir.

\section{Kisitlılıklar}

Bu çalışma, gençlerin gebelik öncesi doğum korkularını yordayıcı faktörleri belirleyen sınırlı literatüre katkı sağlaması bakımından özgün niteliktedir. Buna karşın tek bir üniversitenin tek bir fakültesindeki gençleri temsil etmesi nedeniyle sonuçların genellenemez olması bu çalışmanın bir sınırlılığıdır. Konu ile ilgili eğitim almış öğrencilerin hedefli örneklem olması hem güçlü hem de zayıf tarafıdır. Eğitim bu grupta fark yaratmamış olsa da sağlık alanı dışında eğitim gören öğrencilerin dahil edildiği örneklemlerde fark yaratabilir. Bu sebeple karşılaştırmalı bir çalışma olmaması bir diğer sinırll1ıktır.

\section{Bilgilendirme}

Yazar katkıları: fikir B.A.V., Ş.G.S.; tasarım B.A.V., Ş.G.S., C.O.K.; verilerin toplanması ve analiz için hazırlanması C.O.K, S.B.Y; verilerin analizi B.A.V.; literatür tarama ve makale yazımı B.A.V.; eleştirel değerlendirme Ş.G.S. tarafından yapılmıştır. Araştırma ile ilgili projeden ya da fon desteği alınmamıştır. Araştırmanın yürütüldüğü üniversitenin Girişimsel Olmayan Klinik Araştırmalar Etik Kurulu'ndan onay alınmıştır (Tarih/onay no:10.01.2020/9551). Yazarlar arasında herhangi bir çıkar çatışması bulunmamaktadır. Çalışmaya gönüllü katkı sağlayan tüm katılımcılara teşekkür ederiz. 


\section{Kaynaklar}

1. Nieminen K, Wijma K, Johansson S, Kinberger EK, Ryding EL, Andersson G et al. Severe fear of childbirth indicates high perinatal costs for Swedish women giving birth to their first child. Acta Obstet Gynecol Scand 2017; 96(4):438-446.

2. Nilsson C, Hessman E, Sjöblom H. et al. Definitions, measurements and prevalence of fear of childbirth: a systematic review. BMC Pregnancy Childbirth 2018;18(1):28.

3. Stoll K, Hall W, Janssen P, Carty E. Why are young Canadians afraid of birth? A survey study of childbirth fear and birth preferences among Canadian university students. Midwifery 2014;30(2):220-226.

4. Kapısız Ö, Karaca A, Özkan FS, Savaş HG. Hemşirelik öğrencilerinin doğum algısı. DÜ Sağlık Bil Enst Derg 2017;7(3):156-160.

5. Rodríguez-Almagro J, Hernández-Martínez A, Rodríguez-Almagro D, Quirós-García JM, Martínez-Galiano JM, Gómez-Salgado J. Women's perceptions of living a traumatic childbirth experience and factors related to a birth experience.Int J Environ Res Public Health. 2019;16(9):1654.

6. Clesse C, Lighezzolo-Alnot J, de Lavergne S, Hamlin S, Scheffler, M. (2018). The evolution of birth medicalisation: A systematic review. Midwifery 2018; 66:161-167.

7. Striebich S, Mattern E, Ayerle GM. Support for pregnant women identified with fear of childbirth (FOC)/tokophobia-a systematic review of approaches and interventions. Midwifery 2018;61: 97-115.

8. Henriksen L, Borgen A, Risløkken J, Lukasse M. Fear of birth: Prevalence, counselling and method of birth at five obstetrical units in Norway. Women Birth 2020;33(1):97-104.

9. Adams S, Eberhard-Gran M, Eskild A. Fear of child birth and duration of labor: a study of 2206 women with intended vaginal delivery. BJOG 2012;119:1238-1246.

10. Isbir GG, Sercekus P. The effects of intrapartum supportive care on fear of delivery and labor outcomes: a singleblind randomized controlled trial. J Nurs Res 2017;25(2):112-119.

11. Junges CF, Brüggemann OM, Knobel R, Costa R. Support actions undertaken for the woman by companions in public maternity hospitals. Revi Lat Am Enfermagem 2018;26:e2994.

12. Stoll K, Swift EM, Fairbrother N, Nethery E, Janssen P. A systematic review of nonpharmacological prenatal interventions for pregnancy- specific anxiety and fear of childbirth. Birth 2018;45(1):7-18.

13. MoghaddamHosseini V, Makai A, Varga K, Ács P, Prémusz V, Várnagy Á. Assessing fear of childbirth and its predictors among Hungarian pregnant women using Wijma Delivery Expectancy/Experience Questionnaire subscales. Psychol Health Med 2019;24(7):879-889.

14. Johansson M, Fenwick J. Premberg Å. A meta-synthesis of fathers' experiences of their partner' s labour and the birth of their baby. Midwifery 2015;31(1):9-18.

15. Ghaffari SF, Shahhosseini Z, Nia HS, Elyasi F, Mohammadpoorsaravimozafar, Z. Design and psychometric evaluation of the fathers' fear of childbirth scale: a mixed method study. BMC Pregnancy Childbirth 2021;21:222.

16. Hildingsson I, Johansson M, Fenwick J, Haines H, Rubertsson C. Childbirth fear in expectant fathers: findings from a regional Swedish cohort study. Midwifery 2014;30(2):242-247.

17. Ryding EL, Read S, Rouhe H, Halmesmäki E, Salmela- Aro K, Toivanen R, et al. Partners of nulliparous women with severe fear of childbirth: A longitudinal study of psychological well- being. Birth 2018;45(1):88-93.

18. Serçekuş P, Vardar O, Özkan S. Fear of childbirth among pregnant women and their partners in Turkey. Sex Reprod Healthc 2020;24:100501.

19. Stoll K, Hauck Y, Downe S, Edmonds J, Gross MM, Malott A et al. Cross-cultural development and psychometric evaluation of a measure to assess fear of childbirth prior to pregnancy. Sex Reprod Healthc 2016;8:49-54.

20. Uçar T, Timur Taşhan S. Gebelik öncesi doğum korkusu ölçeğinin Türkçe uyarlaması: kadın ve erkeklerde geçerlik ve güvenirlik çalışması. ACU Sağlık Bil Derg 2018;9:289-96.

21. Hildingsson I, Rubertsson C, Karlström A, Haines H. Exploring the fear of birth scale in a mixed population of women of childbearing age- a Swedish pilot study. Women Birth 2018;31(5):407-413.

22. Li WY, T Liabsuetrakul, B Stray-Pedersen. Change of childbirth preference after delivery among nulliparous Chinese women and their partners. J Obstet Gynaecol Res 2014;40(1):184-191.

23. Bilgin NÇ. Hemşirelik öğrencilerinin doğuma ilişkin algıları: nitel bir çalışma. Düzce Üniversitesi Sağlık Bilimleri Enstitüsü Dergisi 2020;10(3):348-356.

24. Žigić Antić L, Nakić Radoš S, Jokić-Begić N. Are non-pregnant women afraid of childbirth? Prevalence and predictors of fear of childbirth in students. J Psycho Obstet Gynecol 2019; 40(3):226-231.

25. Elvander C, Cnattingius S, Kjerulff KH. Birth experience in women with low, intermediate or high levels of fear: findings from the first baby study Birth 2013;40(4):289-296.

26. Swift EM, Gottfredsdottir H, Zoega H, Gross MM, Stoll K. Opting for natural birth: A survey of birth intentions among young Icelandic women. Sex Reprod Healthc 2017;11:41-46.

27. Hauck YL, Stoll KH, Hall WA, Downie J. Association between childbirth attitudes and fear on birth preferences of a future generation of Australian parents. Women Birth 2016;29(6):511-517.

28. Saroli-Palumbo CS, Hsu R, Tomkinson J, Klein MC. Pre-university students' attitudes and beliefs about childbirth: implications for reproductive health and maternity care. Canadian Journal of Midwifery Research and Practice 2012;11(2):27-37.

29. Kadığlu M, Şahin NH. Üniversite öğrencilerinin doğum şekline yönelik görüşleri, tercihleri ve etkileyen faktörler. Kadın Sağlığı Hemşireliği Dergisi 2019;5(2):43-69.

30. Haines HM, Rubertsson C, Pallant JF, Hildingsson I. The influence of women's fear, attitudes and beliefs of 
childbirth on mode and experience of birth. BMC Pregnancy and Childbirth 2012;12(1):1-14.

31. Hamama-Raz Y, Sommerfeld E, Ken-Dror D, Lacher R, Ben-Ezra M. The role of intra-personal and inter-personal factors in fear of childbirth: a preliminary study. Psychiatr Q 2017;88(2):385-396.

32. Haines H, Rubertsson C, Pallant JF, Hildingsson I. Womens' attitudes and beliefs of childbirth and association with birth preference: a comparison of a Swedish and an Australian sample in mid-pregnancy. Midwifery 2012;28(6): e850-e856.

33. Stützer PP, Berlit S, Lis S, Schmahl C, Sütterlin M, Tuschy B. Elective Caesarean section on maternal request in Germany: factors affecting decision making concerning mode of delivery. Arch Gynecol Obstet 2017;295(5):11511156.

34. Spaich S, Link G, Alvarez SO, Weiss C, Sütterlin M, Tuschy B, Berlit S. Influence of peripartum expectations, mode of delivery, and perineal injury on women's postpartum sexuality. J Sex Med 2020;17(7):1312-13. 